\title{
Strains of Mycobacterium tuberculosis differ in affinity for human osteoblasts and alveolar cells in vitro
}

\author{
Shrabanti Sarkar, Muyalo G. Dlamini, Debapriya Bhattacharya, Olubisi T. Ashiru, A. Willem Sturm \\ and Prashini Moodley*
}

\begin{abstract}
Although the lung is the primary site of infection of tuberculosis, Mycobacterium tuberculosis is capable of causing infection at other sites. In 5-10 \% such extra-pulmonary tuberculosis is located in bone tissue of the spine. It is unknown whether host or microbial factors are responsible for the site where extra-pulmonary tuberculosis manifests itself. One MDR isolate belonging to strain F28, one susceptible F11 and one isolate each of susceptible, MDR and XDR F15/LAM4/KZN were cultured in Middlebrook 7H9 media. Human osteoblasts (SaOS-2) and human alveolar epithelial cells (A549) were exposed to these different isolates of M. tuberculosis and invasion capacity and intra-cellular multiplication rates were established. Mouse macrophage (MHS) cells exposed to M. tuberculosis H37Rv served as control. The invasion capacity of F15/LAM4/KZN representatives increased with the level of resistance. The F28 MDR strain showed similar invasion capacity as the XDR F15/LAM4/KZN for pulmonary epthelial cells, whilst the fully susceptible F11 strain displayed a propensity for osteoblasts. The differences observed may in part explain why certain strains are able to cause infection at specific extra-pulmonary sites. We postulated that the development of extra-pulmonary tuberculosis depends on the ability of the microbe to pass effectively through the alveolar epithelial lining and its affinity for cells other than those in pulmonary tissue.
\end{abstract}

Keywords: Mycobacterium tuberculosis, Extra-pulmonary tuberculosis, XDR F15/LAM4/KZN, Human osteoblasts (SaOS-2), Human alveolar epithelial cells (A549)

\section{Background}

Tuberculosis (TB) is one of the most important causes of morbidity and mortality in the world (Supply et al. 2001). Although drug susceptible TB is a curable disease, it is considered a global public health problem in developing countries (Dye et al. 1999). Worldwide, approximately nine million new TB cases and 1.6 million deaths occur annually (WHO 2012; Adlakha et al. 2012). Mycobacterium tuberculosis is the causative agent of $\mathrm{TB}$. It is a facultative intracellular bacteria that begins the disease in the lung after inhalation of bacilli (Dannenberg 1982).

\footnotetext{
*Correspondence: moodleyp@ukzn.ac.za

Department of Infection Prevention and Control, Nelson R Mandela School of Medicine, School of Laboratory Medicine and Medical Science, College of Health Science, University of KwaZulu-Natal, 719 Umbilo Road, Durban 4075, South Africa
}

Once infection is established, dissemination of the bacilli from the lung into the lymphatics or blood occurs resulting in spread of the infection to other part of the lungs and also to other organ systems (Dannenberg 1982). Macrophages are thought to be the principal host cell (Geiser 2002) which carry the bacilli from the alveolar space into interstitium and bloodstream (Bermudez et al. 2002). However, since there is a predominance of epithelial cells in the lung (Crandall and Kim 1991) these cells may be the first barrier that the organism faces (Adlakha et al. 2012). Earlier studies reported that M. tuberculosis adheres, invades and replicates within pulmonary epithelial cells (Ashiru et al. 2010; Bermudez and Goodman 1996; Mehta et al. 1996). While the lung is the primary site of infection, M. tuberculosis can establish infection in virtually any other organ of the body, known as extrapulmonary tuberculosis. Patients co-infected with HIV

\section{焦 Springer}


show a four-fold higher risk of extra-pulmonary tuberculosis (Kruijshaar and Abubakar 2009). Globally extra-pulmonary tuberculosis accounts for 1-5\% of all TB cases but in South Africa $15 \%$ of all recent cases of TB were extrapulmonary (WHO 2012; Trecarichi et al. 2012).

Osteoblasts originate from the mesenchymal stem cell (Stein et al. 1990; Gandhi et al. 2013). They play a major role in synthesis of bone matrix and regulate the activity of osteoclasts (Gay et al. 2000). It has been reported that Staphylococcus aureus and M. tuberculosis, which are common etiological agents of osteoarticular infections, can infect human osteoblasts in vitro (Jevon et al. 1999; Wright and Friedland 2002). Spinal tuberculosis (Pott's disease) is one of the most devastating, destructive and frequently encountered extrapulmonary forms of the disease. It is characterized by chronic inflammation with massive bone destruction of the spinal vertebrae, causing fracture and collapse of the vertebrae, ultimately resulting in compression of the spinal column with risk of paralysis and neurological deficits (Hoshino et al. 2014).

It is unknown what role host and microbial factors play in the development of Pott's disease and how this compares to pulmonary infection. Approximately $20 \%$ of patients with pulmonary TB develop extra pulmonary infections and $60-75 \%$ of patients with spinal TB have active or latent pulmonary tuberculosis (Garg and Somvanshi 2011). According to Herath et al., the globally reported prevalence of extra-pulmonary tuberculosis ranges from 17 to $52 \%$, with concurrent pulmonary involvement in up to $14 \%$ (Herath and Lewis 2014).

The F15/LAM4/KZN genotype, first reported in the province of KwaZulu-Natal in the early 1990s, has developed into a family of closely related strains accompanied by progression from drug susceptible and multidrugresistant (MDR) to extensively drug-resistant (XDR) (Pillay and Sturm 2007). This genotype has been associated with the largest outbreak of XDR TB reported globally (Gandhi et al. 2013; Pillay and Sturm 2007). The rapid spread of this strain with concomitant high mortality among HIVinfected patients in the Tugela Ferry region of KwaZuluNatal province (Gandhi et al. 2006) suggests increased virulence. Other successful M. tuberculosis strain families are F11 and F28, which were found in more than $70 \%$ of cases of drug-resistant TB in the rural regions of BolandOverberg and Southern Cape-Karoo of the Western Cape Province in South Africa (Streicher et al. 2004). F11 is present in $21.4 \%$ of all infected patients in the Western Cape communities, and is therefore at least as successful as the Beijing genotype which is responsible for $16.5 \%$ of cases (Streicher et al. 2004; Victor et al. 2004). Among the patients with TB from the urban communities in Cape Town, the F28 strain causes disease in $9.7 \%$ of cases. This strain family has not been reported from other parts of South Africa or other regions of Africa. Although F28 appears to be common in the Western Cape Province, comparison of the IS6110-RFLP and the international RIVM spoligotype database suggests that this family may be more wide spread globally than previously thought.

To determine whether F15/LAM4/KZN, F28 and F11 families of $M$. tuberculosis have a specific affinity for bone cells, we studied invasion and intracellular multiplication of pulmonary isolates of these strains in human osteoblasts (SaOS-2) and compared this with invasion and multiplication in pulmonary epithelial cells (A549) and alveolar macrophages (MHS). We also addressed the question whether affinity for osteoblasts in F15/LAM4/KZN strains increased in parallel with development of resistance by including susceptible, MDR, and XDR representatives.

\section{Methods}

Mycobacterium tuberculosis isolates and growth condition

The M. tuberculosis isolates used in this study were retrieved from the culture collection in the Department of Infection Prevention and Control, Nelson R Mandela School of Medicine, School of Laboratory Medicine and Medical Science, College of Health Sciences, University of KwaZulu-Natal. Three of these belonged to the F15/ LAM4/KZN (KZN) family of which one was fully susceptible, one MDR and one XDR. One susceptible isolate belonged to the F11 and one MDR isolate to the F28 family (see Table 1). Laboratory strain H37Rv (ATCC 27294) was included for reference purposes. The isolates were cultured for approximately 3 weeks at $37^{\circ} \mathrm{C}$ in a shaking incubator in Middlebrook 7H9 broth, supplemented with $10 \%$ oleic acid, albumin, dextrose, catalase (OADC), $0.05 \%$ Tween 80 and $0.5 \%$ glycerol.

\section{Inocula preparation}

Cultures were harvested and single cell suspensions were obtained as previously described (Ashiru et al. 2010).

Table 1 Description of different clinical isolates of Mycobacterium tuberculosis used in the experiments (susceptible; MDR: multi-drug resistant; XDR: extensively drug resistant)

\begin{tabular}{lll}
\hline $\begin{array}{l}\text { Mycobacterium tuberculosis } \\
\text { family }\end{array}$ & Strain number & Resistant to \\
\hline F15/LAM4/KZN & V4027 & - \\
F15/LAM4/KZN & MODS 688 & I, R, E, P \\
F15/LAM4/KZN & MODS 388 & I, R, E, P, S, Eth, A, C, K, O \\
F28 & TF 44949 & I, R, E, P \\
LAM3/F11 & TF 832 & - \\
\hline
\end{tabular}

I isoniazid, $R$ rifampin, $E$ ethambutol, $P$ pyrazinamide, $S$ streptomycin, Eth ethionamide, $A$ amikacin, $C$ capreomycin, $K$ kanamycin, $O$ ofloxacin 
Briefly, vortex agitated suspensions were allowed to stand at room temperature for $15 \mathrm{~min}$. Thereafter, the top $6 \mathrm{ml}$ was forced 10 times up and down through a 26 gauge needle and then filtered using a $5 \mu \mathrm{m}$ Millipore filter. To determine the number of colony forming units (CFU) per ml, volumes of $10 \mu \mathrm{l}$ of suspensions with optical density at $600 \mathrm{~nm}$ (OD 600) of 1 were plated in triplicate on OADC enriched Middlebrook 7H11 agar media (Difco).

\section{Cell lines}

Three different cell lines were used for the experiments. A549 human type II alveolar epithelial cells (ATCCCCL185) were cultured in EMEM medium containing $25 \mathrm{mM}$ of HEPES, $10 \%$ heat-inactivated fetal bovine serum (FBS), $2 \mathrm{mM}$ of L-glutamine; MH-S murine alveolar macrophage cells (ATCCCRL2019) in RPMI-1640 medium containing $25 \mathrm{mM}$ of HEPES, $10 \% \mathrm{FBS}, 2 \mathrm{mM}$ of L-glutamine and SaOS-2 human osteoblast cells (ATCC HTB-85) were grown McCoy's 5a medium with $15 \%$ FBS. Semi-confluent monolayers were detached by trypsinization using trypsine-versene (Cambrex BioScience). Trypan blue exclusion was used to determine the number of viable cells using a haemocytometer and $1 \mathrm{ml}$ of the cell suspensions containing $1 \times 10^{5}$ viable cells/ $\mathrm{ml}$ were seeded into each well of a 24-well tissue culture plate. Experiments were done with A549 and MHS cells incubated for $\pm 48 \mathrm{~h}$ at $37^{\circ} \mathrm{C}$ in $5 \% \mathrm{CO}_{2}$ atmosphere at $>90 \%$ confluency, whereas $\mathrm{SaOS}-2$ cells were incubated similarly for $72 \mathrm{~h}$.

\section{Invasion and multiplication assay}

Bacterial invasion was studied as described before (Ashiru et al. 2010) with modifications. Cells were washed thrice with phosphate buffered saline (PBS pH 7.3; Oxoid) maintained at room temperature, after which $1 \mathrm{ml}$ cell-specific culture medium (maintained at room temperature) was added to each well. Following inoculation of the cells with the $M$. tuberculosis suspension at a multiplicity of infection (MOI) of 9-12 per cell, plates were incubated for $2 \mathrm{~h}$ at $37^{\circ} \mathrm{C}$.

To kill extracellular bacteria, aminoglycoside protection assays were performed. This involved exposing the inoculated cells to media containing amikacin $(200 \mu \mathrm{g} /$ $\mathrm{ml}$ ) for $1 \mathrm{~h}$. This concentration of amikacin was used after susceptibility screening had been carried out. Briefly, standardized $M$. tuberculosis inoculum was prepared in volumes of $1 \mathrm{ml}$ as mentioned above using isolates with different susceptibility profiles (susceptible, MDR and $\mathrm{XDR}$ ) and H37Rv. Each suspension was centrifuged at $3000 \times g$ for $20 \mathrm{~min}$. The supernatants were discarded and replaced with $1 \mathrm{ml}$ of media containing different concentrations of amikacin $(20,30,40$ and $50 \mu \mathrm{g} / \mathrm{ml})$. This was followed by brief vortex agitation to resuspend the bacilli and thereafter, the bacterial suspensions were incubated for $1 \mathrm{~h}$ at $37{ }^{\circ} \mathrm{C}$ and plated onto OADC enriched Middlebrook $7 \mathrm{H} 11$ agar plates in triplicate and incubated for 3 weeks to determine the CFU per ml.

After the aminoglycoside protection assay, the cells were washed thrice with PBS, $\mathrm{pH} 7.3$ to remove the amikacin and then lysed with $1 \mathrm{ml}$ of $0.1 \%$ Triton X-100 in distilled water for $20 \mathrm{~min}$. The spent culture medium was plated on OADC enriched Middlebrook 7H11 agarplates and incubated for 3 weeks to check whether all extracellular bacteria were killed. Serial ten-fold dilutions of the lysate were prepared in Middlebrook 7H9 broth with $0.05 \%$ Tween -80 and plated on OADC enriched Middlebrook $7 \mathrm{H} 11$ agar medium. The plates were incubated for 3 weeks in sealed $\mathrm{CO}_{2}$ permeable plastic bags at $37^{\circ} \mathrm{C}$ and the percentage of bacterial invasion was determined based on the obtained colony counts.

To measure intra-cellular multiplication, separate wells with amikacin treated inoculated cells were further incubated in their specific growth media at $37{ }^{\circ} \mathrm{C}$ in $5 \% \mathrm{CO}_{2}$ atmosphere for different time periods. After specific time points $(24,48$ and $72 \mathrm{~h}$ ), the overlaying growth medium was removed and the infected cell monolayers were washed with PBS and lysed as described above. Ten-fold serial dilutions of the lysates were plated in triplicate on OADC enriched 7H11 plates and incubated for 3 weeks for viable count analysis.

\section{Statistical analysis}

All data were analysed by one-way ANOVA (Post Hoc Test: Tukey HSD by means of SPSS software) or student $t$ test. In all cases significance was accepted at $P<0.05$.

\section{Ethics approval}

The study was approved by the Biomedical Research Ethics Committee of the University of KwaZulu-Natal (Reference no: BCA274/09).

\section{Results}

\section{Invasion of Mycobacterium tuberculosis of osteoblasts} and alveolar cell lines

No growth was observed following exposure of $M$. tuberculosis isolates to 30,40 and $50 \mu \mathrm{g} / \mathrm{ml}$ of amikacin respectively including the XDR isolates. There was also no growth from the discarded media following the amikacin protection assay. This further confirmed that only internalized bacilli were reported. The amikacin concentration of $200 \mu \mathrm{g} / \mathrm{ml}$ used in this aminoglycoside protection assay is 100 times higher than the recommended breakpoint for resistance and 10 times higher than the reported concentration that killed extracellular bacilli (Ashiru et al. 2010) and this also kills XDR isolates (WHO 2009). 
Figure 1 shows the invasion capacity of the different isolates in the three cell lines. Based on the invasion capacity into the human osteoblast SaOS-2 cells, two groups of three isolates each could be distinguished. The MDR F28 and drug susceptible KZN isolates grouped together with $\mathrm{H} 37 \mathrm{Rv}$, displaying significantly lower invasion capacity as compared to the second group which included the drug susceptible F11 and the MDR as well as $X D R$ representative of the $K Z N$ strain $(P \leq 0.001)$.

In A549 alveolar epthelial cells, the XDR KZN and the MDR F28 isolates showed almost equal invasion levels $(P>0.05)$ and these were significantly higher than those of the susceptible KZN and the susceptible F11 isolates as well as $\mathrm{H} 37 \mathrm{Rv}(\mathrm{P} \leq 0.001)$. The MDR KZN isolate featured in between with no significant difference with either of those two groups $(\mathrm{P}<0.05)$. H37Rv invaded the mouse alveolar macrophage cell line MHS at levels reported by others (Liu et al. 2013; Sirakova et al. 2003). Like in alveolar epthelial cells, invasion capacity into MHS alveolar macrophages was highest for the XDR KZN and MDR F28 isolates and the difference with the other isolates was statistically significant $(\mathrm{P} \leq 0.001)$. Drug susceptible F11 and both the drug susceptible KZN and MDR KZN isolates, showed similar invasion capacity as H37Rv. Between the two alveolar cell lines, invasion of MHS cells was higher for all isolates $(\mathrm{P} \leq 0.008)$.

\section{Intra-cellular multiplication of Mycobacterium tuberculosis} Intracellular multiplication in bone cells and alveolar cells differed between isolates. In SaOS-2 cells the drug susceptible F11 and both the MDR and XDR KZN isolates

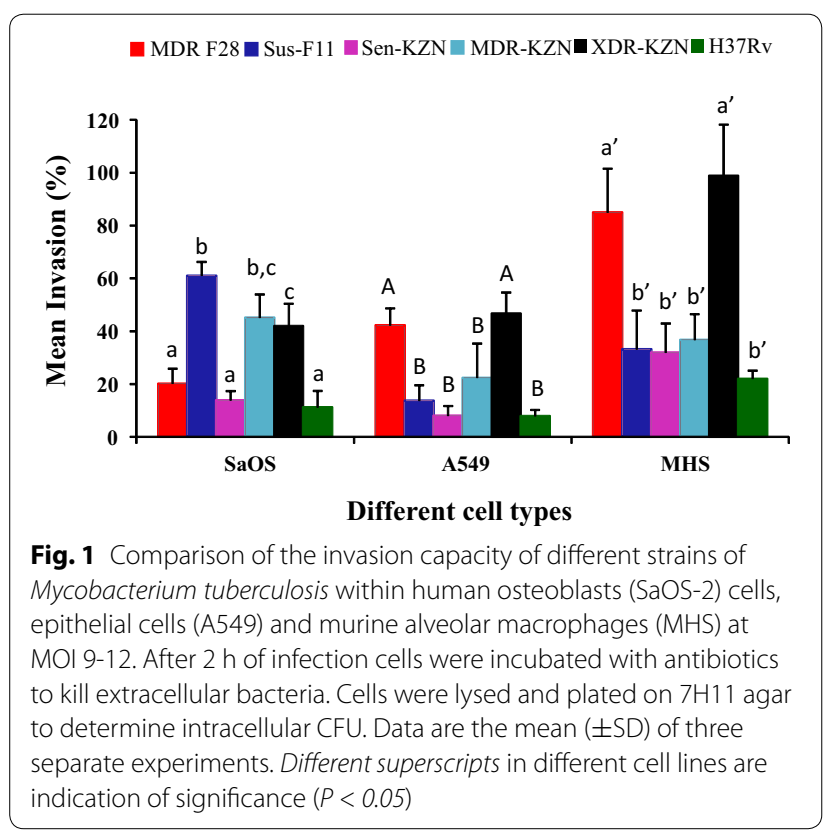

showed the same multiplication pattern. The intracellular number of organisms increased over time at similar rates up to $48 \mathrm{~h}$, with significantly higher number of organisms present at each time point as compared with the other isolates. The calculated growth rate was $0.62 \times$ per $12 \mathrm{~h}$. Between 48 and $72 \mathrm{~h}$, the F11 and XDR KZN isolates kept multiplying with a growth rate of $0.75 \times$ per $12 \mathrm{~h}$ and $0.83 \times$ per $12 \mathrm{~h}$ respectively, but the MDR KZN growth rate became negative $(-0.35 \times$ per $12 \mathrm{~h})$ in that time period. The drug susceptible KZN and MDR F28 isolates showed a multiplication rate of $0.81 \times$ per $12 \mathrm{~h}$ between 2 and $48 \mathrm{~h}$ but growth of H37Rv became negative in the last $24 \mathrm{~h}$ (Fig. 2a).

In A549 cells, the intracellular number of organisms of the XDR KZN and drug susceptible KZN isolates increased at similar rate $(0.69 \times$ per $12 \mathrm{~h})$ up to $48 \mathrm{~h}$ and after that time point XDR KZN isolates showed a progressive increase with a multiplication rate of $0.77 \times$ per $12 \mathrm{~h}$ from the 48 -h time point to $72 \mathrm{~h}$ of incubation. The growth rate of the drug susceptible KZN isolate became negative $(-0.33 \times$ per $12 \mathrm{~h}$ ) in that time period. After $24 \mathrm{~h}$, MDR F28 and drug susceptible F11 isolates exhibited a similar multiplication pattern with negative growth rate $(-0.2 \times$ per $12 \mathrm{~h})$ from 48 to $72 \mathrm{~h}$. Multiplication of the MDR KZN isolate stopped after $24 \mathrm{~h}$ and consequently over the next $48 \mathrm{~h}$ the number of organisms remained stable. Multiplication of $\mathrm{H} 37 \mathrm{Rv}$ was significantly slower than any of the clinical isolates during the $72 \mathrm{~h}$ of incubation (Fig. 2b).

Intracellular multiplication in alveolar macrophages differed between isolates. In MHS cells the drug susceptible F11 and both the drug susceptible KZN and MDR $\mathrm{KZN}$ isolates showed the same multiplication pattern. After initial entry, the intracellular number of organisms of all three isolates displayed a slow growth rate (both KZN isolates) or numbers remained stable (F11) up to $24 \mathrm{~h}$ and then increased up to $72 \mathrm{~h}$. The calculated growth rate during that period was $0.72 \times$ per $12 \mathrm{~h}$. The MDR F28 isolates showed a decrease in numbers during the first $24 \mathrm{~h}$ but then started to increase at a multiplication rate of $0.73 \times$ per $12 \mathrm{~h}$ between 24 and $72 \mathrm{~h}$. At each time point a significantly $(P \leq 0.001)$ higher number of organisms of the XDR KZN isolate was present when compared to the other isolates. The calculated growth rate was $0.54 \times$ per $12 \mathrm{~h}$ between 24 and $72 \mathrm{~h}$. H37Rv displayed a slow growth rate up to $48 \mathrm{~h}$ with acceleration in the last $24 \mathrm{~h}$. This was comparable with F11 and the susceptible and MDR-KZN isolates but significantly $(P<0.05)$ lower compared to XDR KZN or MDR F28 (Fig. 2c).

\section{Discussion}

Extra-pulmonary tuberculosis occurs in any part of the body. The port of entry for M. tuberculosis is the lung. 


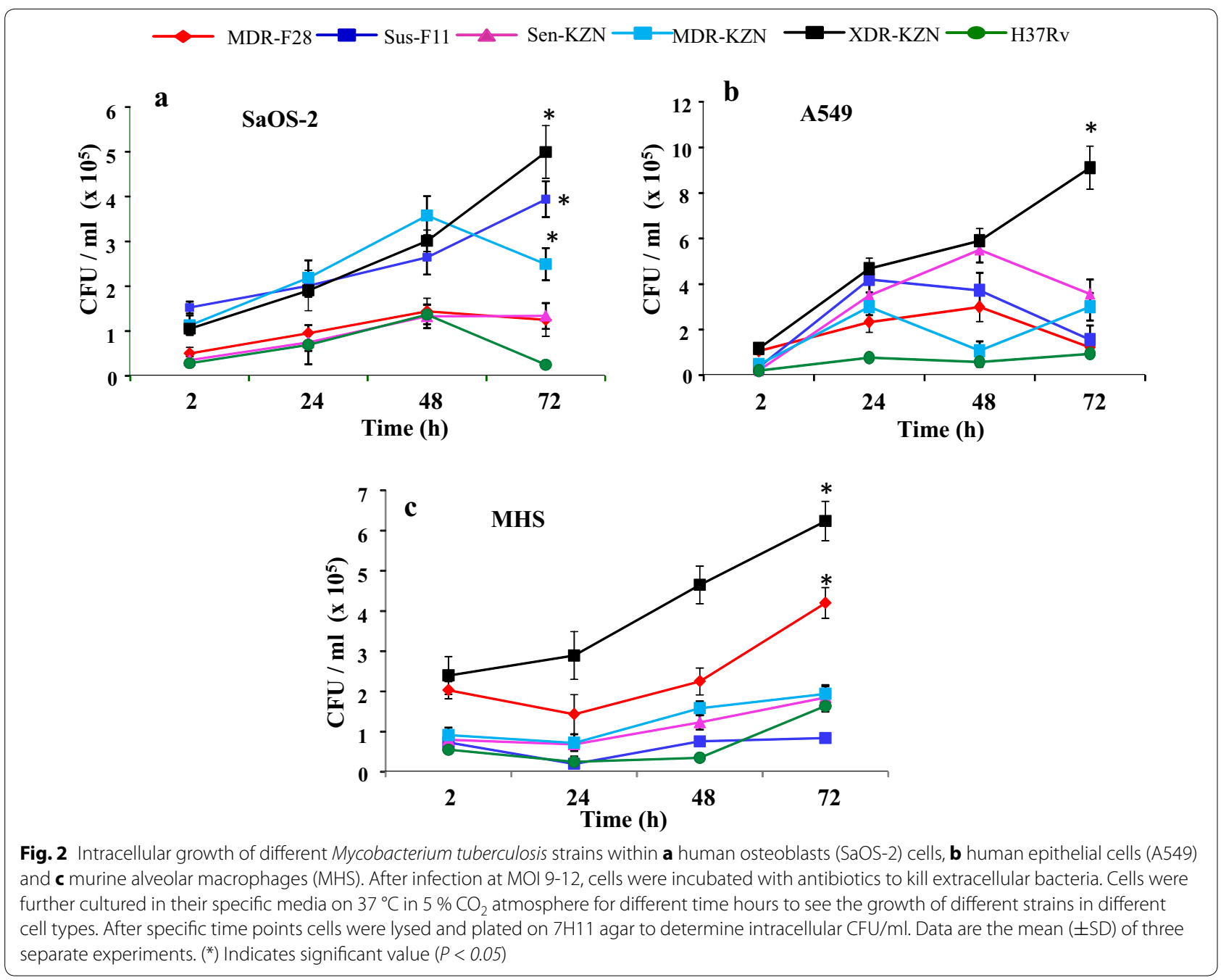

Spread through the body is thought to occur by transport inside migrating macrophages as well as through bacteraemia (Dannenberg and Rook 1994; Edwards and Kirkpatrick 1986). The site where the bacteria settle and later on develop extra-pulmonary tuberculosis was thought to be random. However, some recent studies reported associations between $M$. tuberculosis strains and site of extrapulmonary disease (Adlakha et al. 2012; Be et al. 2012; Caws et al. 2008; Click et al. 2012; Garcia de Viedma 2003; Hernandez Pando et al. 2010; Lari et al. 2009). We postulated that the development of extra-pulmonary tuberculosis depends on the ability of the microbe to pass effectively through the alveolar epithelial lining and its affinity for cells other than those in pulmonary tissue. Since Pott's disease is a frequently diagnosed form of extra-pulmonary tuberculosis, we chose human osteoblasts as the extra-pulmonary cell type. Hoshino et al. (2014) reported that $M$. tuberculosis strains can multiply in bone cells. However, they used osteoclasts in stead of osteoblasts. We chose osteoblasts based on the findings of Wright and Friedland (2002) who reported that in these cells the production of pro-inflammatory cytokines is upregulated when infected with M. tuberculosis or $S$. aureus. It is therefore likely that osteoblasts are essential in the development of Pott's disease.

The MHS mouse macrophage cell line exposed to $M$. tuberculosis $\mathrm{H} 37 \mathrm{Rv}$ served as control. We found that there are indeed major differences between the strains of M. tuberculosis. Based on former work in our laboratory with A549 cells in which we found differences between F15/LAM4/KZN isolates, we also included isolates of this strain with different resistance profiles (Ashiru et al. 2010).

Our results indicate that there are differences in invasion and intracellular multiplication between strains in alveolar epithelium and that for F15/LAM4/KZN invasion capacity increases with the level of resistance. Of the other two strains tested, the F28 strain showed similar 
invasion capacity as the XDR F15/LAM4/KZN. Whether this is related to the fact that the F28 isolate used had the MDR resistance profile needs further investigation. The observations with the osteoblast cell line differed in that now, the fully susceptible F11 isolate was the most invasive strain. Interestingly, while the susceptible F15/ LAM4/KZN isolate's invasion capacity in osteoblasts was low and comparable with H37Rv, the MDR and XDR isolates of this strain invaded at a much higher rate. Similarly, both resistant isolates of F15/LAM4/KZN showed a significantly higher multiplication rate in these cells. We conclude that in parallel to the development to MDR, a genetic event occurred that increased the affinity of the strain to bone tissue. This needs further exploration.

We explained the difference in the number of intracellular organisms between the isolates by differences in multiplication rate. We considered the possibility that the isolates with lower intracellular numbers were cytotoxic and therefore had fewer or less viable cells available. Although we did not test for cytotoxicity, this explanation seems unlikely since we did not observe any microscopic differences between the SaOS-2 cells exposed to the different isolates.

Passing of the mycobacteria through lung tissue into other parts of the body can be through transepithelial migration (Birkness et al. 1999) or through destruction of lung tissue (Danelishvili et al. 2003). Whether transepithelial migration occurs needs to be investigated. However, we do have evidence that cytoxic effect on A549 cells is highest in resistant isolates of F15/LAM4/KZN (Ashiru and Sturm 2015).

Most studies on interaction of Mycobacterium tuberculosis with alveolar cell types involve alveolar macrophages (Crouch et al. 2000; McCormack and Whitsett 2002). These large pleomorphic cells are found within lung alveoli as free cells or attached to the respiratory epithelium and are classically thought to be the first cell to respond to inhaled pathogens (Geiser 2002; Crouch et al. 2000; McCormack and Whitsett 2002). MHS cells are a useful model for the in vitro study of alveolar macrophages. Like in primary alveolar macrophages, Mycobacterium tuberculosis survives in MHS cells after infection (Melo and Stokes 2000). Our findings are in agreement with previous studies that Mycobacterium tuberculosis strains invade both A549 and MHS cells. However our results revealed that different strains showed distinct invasion capacity for different cell types and in general invasion capacity in MHS cells was higher compared to A549. This is similar with the findings of Mehta et al. (1996) who reported that in the epithelial cells bacterial uptake may be at a lower rate compared with macrophages (Mehta et al. 1996). The contribution of invasion of each of these alveolar cell types in the further development to extra-pulmonary tuberculosis needs additional investigations.

\section{Conclusion}

It has been previously assumed that the site of extrapulmonary tuberculosis (EPT) in individual patients was an event likely to be random, or at most influenced by host factors only. Recently, there is accumulating evidence that shows significant differences between strains of Mycobacterium tuberculosis. In this paper we postulated that the site of EPT was at least partly determined by bacterial characteristics.

\section{Authors' contributions}

Conceived and designed the experiments: SS, AWS, PM. Performed the experiments: SS, MGD, DB, OTA. Analyzed the data: SS, DB, AWS, PM. Wrote the paper: SS, OTA, AWS, PM. All authors read and approved the final manuscript.

\section{Competing interests}

The authors declare that they have no competing interests.

\section{Funding}

This study was funded by the Department of Infection Prevention and Control, Nelson R Mandela School of Medicine, University of KwaZulu-Natal, Durban, South Africa.

Received: 8 October 2015 Accepted: 15 February 2016

Published online: 24 February 2016

\section{References}

Adlakha N, Vir P, Verma I (2012) Effect of mycobacterial secretory proteins on the cellular integrity and cytokine profile of type II alveolar epithelial cells. Lung India 29:313-318

Ashiru OT, Sturm AW (2015) Cytotoxicity induction in A549 Alveolar epithelial cells by Mycobacterium tuberculosis isolates cultured in the presence and absence of oxygen. J Basic Appl Sci 11:118-124

Ashiru OT, Pillay M, Sturm AW (2010) Adhesion to and invasion of pulmonary epithelial cells by the F15/LAM4/KZN and Beijing strains of Mycobacterium tuberculosis. J Med Microbiol 59:528-533

Be NA, Bishai WR, Jain SK (2012) Role of Mycobacterium tuberculosis pknD in the pathogenesis of central nervous system tuberculosis. BMC Microbiol $12: 7$

Bermudez LE, Goodman J (1996) Mycobacterium tuberculosis invades and replicates within type II alveolar cells. Infect Immun 64:1400-1406

Bermudez LE, Sangari FJ, Kolonoski P, Petrofsky M, Goodman J (2002) The efficiency of the translocation of Mycobacterium tuberculosis across a bilayer of epithelial and endothelial cells as a model of the alveolar wall is a consequence of transport within mononuclear phagocytes and invasion of alveolar epithelial cells. Infect Immun 70:140-146

Birkness KA, Deslauriers M, Bartlett JH, White EH, King CH et al (1999) An in vitro tissue culture bilayer model to examine early events in Mycobacterium tuberculosis infection. Infect Immun 67:653-658

Caws M, Thwaites G, Dunstan S, Hawn TR, Lan NT et al (2008) The influence of host and bacterial genotype on the development of disseminated disease with Mycobacterium tuberculosis. PLoS Pathog 4:e1000034

Click ES, Moonan PK, Winston CA, Cowan LS, Oeltmann JE (2012) Relationship between Mycobacterium tuberculosis phylogenetic lineage and clinical site of tuberculosis. Clin Infect Dis 54:211-219

Crandall ED, Kim KJ (1991) Alveolar epithelial barrier properties. In: Crystal RJ, West JB (eds) The lung: scientific foundations. Raven Press, New York, pp 273-287

Crouch E, Hartshorn K, Ofek I (2000) Collectins and pulmonary innate immunity. Immunol Rev 173:52-65 
Danelishvili L, McGarvey J, Li YJ, Bermudez LE (2003) Mycobacterium tuberculosis infection causes different levels of apoptosis and necrosis in human macrophages and alveolar epithelial cells. Cell Microbiol 5:649-660

Dannenberg AM Jr (1982) Pathogenesis of pulmonary tuberculosis. Am Rev Respir Dis 125:25-29

Dannenberg AM Jr, Rook GAW (1994) Pathogenesis of pulmonary tuberculosis; an interplay of tissue-damaging and macrophage-activating immune responses-dual mechanisms that control bacillary multiplication. In: Bloom BR (ed) Tuberculosis: pathogenesis, protection, and control. ASM Press, Washington, DC, pp 459-483

Dye C, Scheele S, Dolin P, Pathania V, Raviglione MC (1999) Consensus statement. Global burden of tuberculosis: estimated incidence, prevalence, and mortality by country. WHO Global Surveillance and Monitoring Project. JAMA 282:677-686

Edwards D, Kirkpatrick CH (1986) The immunology of mycobacterial diseases. Am Rev Respir Dis 134:1062-1071

Gandhi NR, Moll A, Sturm AW, Pawinski R, Govender T et al (2006) Extensively drug-resistant tuberculosis as a cause of death in patients co-infected with tuberculosis and HIV in a rural area of South Africa. Lancet 368:1575-1580

Gandhi NR, Weissman D, Moodley P, Ramathal M, Elson l et al (2013) Nosocomial transmission of extensively drug-resistant tuberculosis in a rural hospital in South Africa. J Infect Dis 207:9-17

Garcia de Viedma D (2003) Rapid detection of resistance in Mycobacterium tuberculosis: a review discussing molecular approaches. Clin Microbiol Infect 9:349-359

Garg RK, Somvanshi DS (2011) Spinal tuberculosis: a review. J Spinal Cord Med 34:440-454

Gay CV, Gilman VR, Sugiyama T (2000) Perspectives on osteoblast and osteoclast function. Poult Sci 79:1005-1008

Geiser M (2002) Morphological aspects of particle uptake by lung phagocytes. Microsc Res Tech 57:512-522

Herath S, Lewis C (2014) Pulmonary involvement in patients presenting with extra-pulmonary tuberculosis: thinking beyond a normal chest x-ray. J Prim Health Care 6:64-68

Hernandez Pando R, Aguilar D, Cohen I, Guerrero M, Ribon W et al (2010) Specific bacterial genotypes of Mycobacterium tuberculosis cause extensive dissemination and brain infection in an experimental model. Tuberculosis (Edinb) 90:268-277

Hoshino A, Hanada S, Yamada H, Mii S, Takahashi M et al (2014) Mycobacterium tuberculosis escapes from the phagosomes of infected human osteoclasts reprograms osteoclast development via dysregulation of cytokines and chemokines. Pathog Dis 70:28-39

Jevon M, Guo C, Ma B, Mordan N, Nair SP et al (1999) Mechanisms of internalization of Staphylococcus aureus by cultured human osteoblasts. Infect Immun 67:2677-2681

Kruijshaar ME, Abubakar I (2009) Increase in extrapulmonary tuberculosis in England and Wales 1999-2006. Thorax 64:1090-1095
Lari N, Rindi L, Cristofani R, Rastogi N, Tortoli E et al (2009) Association of Mycobacterium tuberculosis complex isolates of BOVIS and Central Asian (CAS) genotypic lineages with extrapulmonary disease. Clin Microbiol Infect 15:538-543

Liu CF, Tonini L, Malaga W, Beau M, Stella A et al (2013) Bacterial protein-Omannosylating enzyme is crucial for virulence of Mycobacterium tuberculosis. Proc Natl Acad Sci USA 110:6560-6565

McCormack FX, Whitsett JA (2002) The pulmonary collectins, SP-A and SP-D, orchestrate innate immunity in the lung. J Clin Invest 109:707-712

Mehta PK, King CH, White EH, Murtagh JJ Jr, Quinn FD (1996) Comparison of in vitro models for the study of Mycobacterium tuberculosis invasion and intracellular replication. Infect Immun 64:2673-2679

Melo MD, Stokes RW (2000) Interaction of Mycobacterium tuberculosis with $\mathrm{MH}-\mathrm{S}$, an immortalized murine alveolar macrophage cell line: a comparison with primary murine macrophages. Tuber Lung Dis 80:35-46

Pillay M, Sturm AW (2007) Evolution of the extensively drug-resistant F15/ LAM4/KZN strain of Mycobacterium tuberculosis in KwaZulu-Natal, South Africa. Clin Infect Dis 45:1409-1414

Sirakova TD, Dubey VS, Cynamon MH, Kolattukudy PE (2003) Attenuation of Mycobacterium tuberculosis by disruption of a mas-like gene or a chalcone synthase-like gene, which causes deficiency in dimycocerosyl phthiocerol synthesis. J Bacteriol 185:2999-3008

Stein GS, Lian JB, Owen TA (1990) Relationship of cell growth to the regulation of tissue-specific gene expression during osteoblast differentiation. FASEB J 4:3111-3123

Streicher EM, Warren RM, Kewley C, Simpson J, Rastogi N et al (2004) Genotypic and phenotypic characterization of drug-resistant Mycobacterium tuberculosis isolates from rural districts of the Western Cape Province of South Africa. J Clin Microbiol 42:891-894

Supply P, Lesjean S, Savine E, Kremer K, van Soolingen D et al (2001) Automated high-throughput genotyping for study of global epidemiology of Mycobacterium tuberculosis based on mycobacterial interspersed repetitive units. J Clin Microbiol 39:3563-3571

Trecarichi EM, Di Meco E, Mazzotta V, Fantoni M (2012) Tuberculous spondylodiscitis: epidemiology, clinical features, treatment, and outcome. Eur Rev Med Pharmacol Sci 2:58-72

Victor TC, de Haas PE, Jordaan AM, van der Spuy GD, Richardson M et al (2004) Molecular characteristics and global spread of Mycobacterium tuberculosis with a western cape F11 genotype. J Clin Microbiol 42:769-772

WHO (2009) Guidelines for surveillance of drug resistance in tuberculosis, Fourth edition

WHO (2012) WHO Global tuberculosis report 2012. Geneva

Wright KM, Friedland JS (2002) Differential regulation of chemokine secretion in tuberculous and staphylococcal osteomyelitis. J Bone Miner Res $17: 1680-1690$

\section{Submit your manuscript to a SpringerOpen ${ }^{\circ}$ journal and benefit from:}

- Convenient online submission

- Rigorous peer review

- Immediate publication on acceptance

- Open access: articles freely available online

- High visibility within the field

- Retaining the copyright to your article

Submit your next manuscript at springeropen.com 